\title{
PERSEPSI DAN PREFERENSI MASYARAKAT TERHADAP FASAD BANGUNAN DI KORIDOR JALAN KI SAMAUN KOTA TANGERANG
}

\author{
People's Perceptions and Preferences on Building Façade \\ in Ki Samaun Street Corridor, Tangerang City.
}

Nur Sukma Suri ${ }^{1}$ dan Agung Sugiri

Diterima: 29 Juni 2015 Disetujui: 19 Agustus 2015

\begin{abstract}
Abstrak: Studi ini dilakukan untuk mengetahui persepsi dan preferensi masyarakat terhadap fasad bangunan. Metode campuran antara kualitataif dan kuantitatif digunakan sebagai bentuk triangulasi dengan metode analisis berurutan dari dekriptif kualitataif ke deskriptif kuantitatif. Data didapatkan dari wawancara kepada perangkat dinas, kelurahan dan budayawan di Kota Lama dan kuesioner semi-terbuka kepada masyarakat yang beraktivitas di sepanjang koridor jalan Ki Samaun. Temuan studi ini menunjukkan bahwa warna; gaya arsitektur; lebar dan tinggi bangunan, ornament bangunan merupakan elemen terpenting yang digunakan untuk mengukur persepsi dan preferensi masyarakat terhadap fasad bangunan. Studi ini juga menunjukan bahwa terdapat keselarasan antara persepsi dan preferensi masyarakat dengan rencana revitalisasi Kota Lama. Keduanya berpendapat bahwa warna bangunan terlihat seragam, tidak memberikan rasa senang, dan terdapat bangunan dengan warna yang lebih mencolok dari bangunan lainnya. Kedua juga berpendapat bahwa gaya arsitektur bangunan di KoridorJalan Ki Samaun tidak lagi mencerminkan budaya pecinan, dan upaya restorasi diperlukan untuk mengembalikan bangunan kebentuk aslinya. Kedua pihak juga berpendapat bahwa tinggi dan lebar bangunan tidaksama, tetapi upaya renovasi tidak perlu dilakukan. Kedua pihak juga berpendapat bahwa tidak ada bangunan di Koridor Jalan Ki Samaun yang memiliki ornament serupa; signage merupakan sumber polusi visual kawasan dan penataan ulang signage perlu untuk dilakukan.
\end{abstract}

Kata Kunci :PersepsidanPreferensiMasyarakat, FasadBangunan, RevitalisasiJalan Heritage Perkotaan.

Abstract: This research aims to discover people's perceptions and preferences towards building façade. This research has used a mixed-method approach with the triangulation of data validation. In the analysis, a sequence-analysis method has been utilized, beginning from qualitative descriptive to quantitative one. Data were collected from in-depth-interview with several key persons like district official, officers of certain governmental departments, and questionnaire distribution to the people who have their daily activities in Ki SamaunStreet, which is part of Kota Lama area in Tangerang City. The findings of this study show that colors; architectural design; width and height of the buildings and building-'s' ornaments are the most important elements in building façade that can be used to comprehend the people's perceptions and preferences. This study has found that there are similarities between people's perceptions and preferences with the

${ }^{1}$ Jurusan Perencanaan Wilayah dan Kota, Universitas Diponegoro 
Kota Lama's development plans. Both sides are of the opinion that the colors of the buildings are similar, unpleasant, and there are some buildings more stand out than the others. Both sides also perceive that the architectural style of the buildings no longer represents the Chinese culture. This makes the restoration work to reverse the façade back into its original form is essential. Both sides also recognize that building-'s' height and width are not in harmony, although the people think that renovation is not needed. Both sides also observe that there are no buildingswith similar ornaments; whilesignage is the main source of visual pollution and rearrangement of signage is needed.

Keywords: People's perception and preferences, building façade, urban heritage,corridor revitalization

\section{Pendahuluan}

Jalan Ki Samaun merupakan salah satu kawasan yang memiliki potensi wisata budaya di Kota Tangerang yang menawarkan bangunan bersejarah dengan nuansa pecinan. Saat ini Koridor Jalan Ki Samaun dikenal sebagai kawasan perdagangan dan jasa yang menyediakan keperluan sehari - hari serta keperluan khusus untuk perayaan festival kebudayaan cina seperti imlek, cap go meh, dan lain sebagainya dengan harga yang terjangkau. Kondisi tersebut menjadikan Koridor Ki Samaun sebagai tujuan utama bagi masyarakat tionghoa dari dalam dan luar Kota Tangerang untuk berbelanja keperluan festival tahunan tersebut, namun akibat perkembangan Kota Tangerang yang pesat dengan disertai munculnya pusat - pusat perbelanjaan baru di sekitar pasar lama membuat keberadaan pasar lama sedikit terlupakan. Ditambah lagi dengan perubahan fisik kawasan, terutama fasad bangunannya membuat kawasan ini semakin terancam identitasnya.

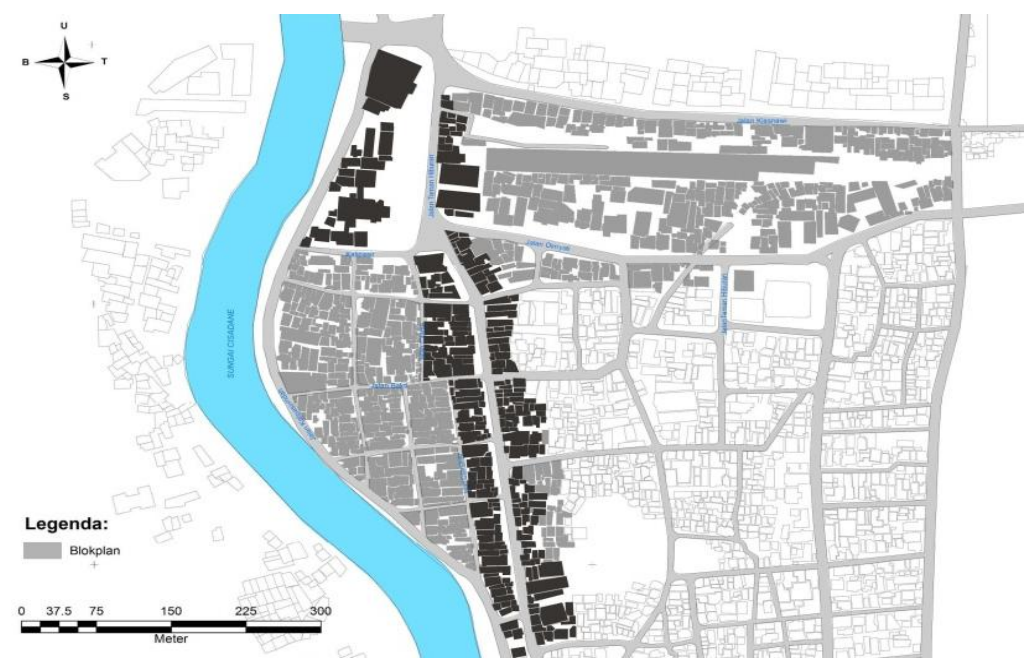

(DiperolehdariBappeda, 2015,denganModifikasi)

\section{Gambar 1. Lokasi Koridor Jalan Ki Samaun Kota Lama Tangerang}

Salah satu tujuan dari pengembangan Kota Lama sebagai aset wisata budaya Tangerang adalah mempertahankan bangunan bersejarah untuk menjaga keberlanjutan nilai historis dan kultural kawasan. Untuk mewujudkan tujuan tersebut, pemerintah Kota Tangerang di dalam RTBL kawasan kota lama menetapkan bahwa bangunan yang masih 
memiliki gaya arsitektur pecinan akan tetap dipertahankan dan bagi bangunan yang berubah nantinya akan direstorasi sesuai dengan kebutuhan.

Tujuan dan kebijakan tersebut tentu menjadi tantangan bagi pemerintah Kota Tangerang, terutama jika mengingat kebanyakan bangunan bersejarah yang ada di koridor Jalan Ki Samaun merupakan bangunan ruko dengan hak milik perseorangan, sehingga pemeliharan bangunan diserahkan sepenuhnya kepada pemilik bangunan. Kondisi fisik bangunan sangat bergantung kepada kemampuan dan kreativitas pemilik bangunan, baik itu pilihan untuk meningkatkan tampilan bangunan atau tetap hidup dengan kondisi eksisting bangunannya. Ditambah lagi Kota Lama juga tidak memiliki peraturan khusus mengenai fasad bangunan biarpun kebijakan mengenai penataan bangunan sudah diatur namun belum disahkan, sehingga memungkinkan pemilik bangunan untuk merubah fungsi dan tampilan bangunan, terutama jika bangunan tersebut terletak di lokasi yang memiliki aktivitas komersial yang tinggi (Aminuddin dalam Hibrawan, 2008).

Selain permasalahan di atas, tumbuh dan berkembangnya beragam bangunan baru pada kedua sisi ruang jalan Koridor Jalan Ki Samaun yang muncul dengan gaya arsitektur yang berbeda - beda seakan saling berlomba menunjukkan identitas masing - masing ini cenderung tidak selaras dengan karakter tempat sehingga pada akhirnya berdampak pada penurunan karakter visual kawasan. Disisi lain, pengendalian pembangunan yang terjadi diruang jalan Koridor Jalan Ki Samaun tidak dapat dilakukan karena tidak adanya design guidelines untuk tetap menjaga karakter visual yang ada. Apabila perubahan yang dilakukan tidak mengacu pada arahan yang tepat, dikhawatirkan pada akhirnya penurunan kualitas visual yang terjadi akan membuat ruang jalan Koridor Jalan Ki Samaun sulit untuk dikenali dan dipahami dengan nyaman dan aman oleh penggunanya, terutama mengingat tampilan bangunan (fasad) telah banyak berubah.

Berdasarkan kondisi di atas, maka diperlukan kajian mengenai karakter fisik kawasan, terutama dalam penataan bangunannya, karena pada dasarnya identitas sebuah distrik bersejarah dalam suatu kota direpresentasikan oleh fasad bangunannya yang khas (Askari et al, 2013). Studi ini dilakukan untuk mengetahui pandangan persepsi dan preferensi masyarakat mengenai fasad bangunan di Koridor Jalan Ki Samaun yang merupakan representasi dari identitas kawasan, sekaligus memberi pengetahuan kepada masyarakat betapa pentingnya nilai-nilai yang terkandung dalam bangunan bersejarah yang ada di lingkungan sekitar mereka. Meskipun terdapat perubahan, maka diharapkan perubahan tersebut tidak mengurangi nilai karakter fasade langgam yang digunakan, sehingga nilai karakter atau kekuatan tempat di koridor Jalan Ki Samaun tetap terjaga.

\section{Persepsi Dan Preferensi Masyarakat Terhadap Fasad Bangunan}

Berdasarkan Kaplan dan Kaplan (dalam dalam Utaberta, N. et al, 2012), preferensi merupakan produk dari persepsi. Pertama, telah diasumsikan bahwa persepsi memang diarahkan untuk membentuk sense suatu lingkungan; kedua, persepsi merupakan proses yang sangat inferensial, dimana proses terset membutuhkan pengetahuan, pegalaman dan interpretasi yang tetap. Persepsi juga merupakan salah satu proses fisik-psikis yang dilalui oleh manusia untuk mendapatkan informasi mengenai lingkungan tertentu (Kimball, 1917 dalam Utaberta, N. et al, 2012).

Persepsi melibatkan proses kognitif yang lebih sulit dibuat oleh publik pada umumnya, oleh karena itulah preferensi terpilih sebagau pendekatan yang paling cocok dalam penelitian ini. Pada umumnya, di dalam beberapa studi mengenai fasad dan bangunan, adalah respon persepsi sederhana yang melibatkan penilaian yang dibuat orang - orang terhadap sesuatu yang mereke inginkan lebih dari yang lainnya. Namun, untuk mendapatkan preferensi terhadap lingkungan perkotaan, berbagai informasi yang tersimpan dalam pikiran manusia mengenai kondisi lingkungan saat ini (Moula, F. dalam 
Utaberta, N. et al, 2012). Preferensi mengenai fasad bangunan dapat dihasilkan dari kegiatan evaluasi fasad bangunan.

Berbagai Studi telah menjelaskan bahwa kualitas lingkungan terbangun dievaluasi melalui fitur fisiknya (Brown and Giffted, 2001), namun, representasi mental publik terhadap bangunan biasanya di dapatkan dari evaluasi fasad (Imamoglu, dalam Utaberta, N. et al, 2012), dengan kata lain, penampilan bangunan jelas memainkan peran penting dalam evaluasi lingkungan fisik. Tidak hanya itu, beberapa penelitian juga mendeskripsikan bahwa posisi emosional dari pengamat dalam mengevaluasi kualitas arsitektur dari lingkungan terbangun menjadi salah satu faktor penting selain fitur fisik itu sendiri (Mehrabian dan Russell, 1974; Gifford et al., 2000 dalam Utaberta, N. et al, 2012). Faktor faktor yang mempengaruhi evaluasi terhadap lingkungan terbangunan jika ditinjau dari fitur exteriornya adalah kebersihan, ornamen, detil dan isi (Akalin, et al., 2009; Nasar 1983 dalam Utaberta, N. et al, 2012).

Beberapa studi terdahulu juga mengidentifikasi bahwa elemen - elemen yang dapat digunakan untuk mengevaluasi fasad bangunan, contohnya dari segi gaya arsitektur bangunan elemen yang perlu diperhatikan adalah usia bangunan, nilai bangunan, besar, bentuk, pencahayaan, warna dan material yang digunakan (Nasar, 1989; Hui, 2007; Karaman; 2005). Sedangkan untuk bangunan bersejarah, elemen yang perlu diperhatikan adalah warna, material informasi mengenai identitas dan latar belakang dibangunnnya bangunan tersebut, kegunaan atau fungsi, tingkat familiaritas bangunan (Coeterier, 2002). Lebih lanjut Coeterier (2002) menyebutkan bahwa kriteria untuk daya tarik bangunan bersejarah adalah warna, material yang digunakan, dan proporsi.

Brown and Gifford (2001) menyebutkan enam faktor kognitif dalam evaluasi fasad bangunan yaitu kejelasan (clarity), kompleasitas (complexity), keramahtamahan (friendliness), orisinalitas (originality), ketidakrataan (ruggedness), dan kemaknaan (meaningfulness). Beberapa studi percaya bahwa emosi terhadap suatu bangunan dapat mempengaruhi evaluasi seseorang terhadap fasad bangunan. Cubukcu dan Kahraman (2008) menjelaskan bahwa evaluasi terhadap fasad bangunan dapat dinyatakan cukup layak melalui pengukuran preferensi (suka-tidak suka), rangsangan (menarik-tidak menarik), kealamian (natural-buatan), dan relaksasi (membuat relaks-membuat stress).

\section{Metode Penelitian}

Metode penelitian yang dipakai dalam penelitian ini yaitu metode campuran atau mixed-method. Berdasarkan klasifikasi metode campuran Tashakkori dan Teddlie (2003), metode mixed-method dalam penelitian ini termasuk dalam desain exploratory dengan model pengembangan taxonomi yang berarti ada dua tahap berurutan KUAL/Kuan yang saling melengkapi (Creswell dan Clark, 2007). Penekanan metode ada pada KUAL dengan metode kuan dipakai sebagai verifikasi dari informasi yang didapatkan dari metode KUAL.

Pengumpulan data kualitatif dari wawancara semi terbuka kepada 4 responden, yaitu Bappeda Kota Tangerang, Dinas Pariwisata Kota Tangerang, Kepala Lurah Sukasari dan Staff Museum Benteng Heritage. Sedangkan data kuantitatif didapat dari kuesioner yang disebar secara acak kepada 70 reponden dari 220 pedagang/pemilik gedung/wiraswatawan yang beraktivitas di Koridor Ki Samaun. Kuesioner tersebut berisikan penilaian (berdasarkan persepsi masyarakat) terhadap 4 fungsi fasad bangunan sebagai pembentuk keserasian visual kawasan, dan penilaian preferensi masyarakat akan 4 aspek prioritas dalam perbaikan tampilan fasad bangunan sebagai pembentuk keserasian visual kawasan. Penilaian tersebut menggunakan skala likert 1-5 dimana 1 untuk nilai terendah (sangat tidak setuju) dan 5 untuk nilai tertinggi (sangat setuju). Penilaian ini nantinya akan digunakan dalam analisis persepsi dan preferensi masyarakat terhadap fasad bangunan di koridor ki samaun sebagai analisis deskriptif kuantitatif. 


\section{Historis Kawasan Dan Efektivitas Pelaksanaan Program Revitalisasi Koridor Ki Samaun}

Kota lama diperkirakan terbentuk sejak tahun 1700an, diawali dengan datangnya orang - orang tionghoa dengan tujuan berdagang dan pada akhirnya menetap di beberapa wilayah pinggiran sungai cisadane yang tersebar di Kota Tangerang. Aktivitas kawasan pada saat itu dipengaruhi oleh pendudukan kolonial yang memindahkan masyarakat cina di Kota Tangerang ke daerah Kota Lama (kampung petak Sembilan), dan memberikan mereka ladang pertanian untuk diolah, sehingga aktivitas masyakat pada saat itu adalah perdagangan dan pertanian.

Pada abad ke-18 pemerintah belanda kemudian membangun stasiun KA Tangerang yang digunakan untuk mengangkut komoditas hasil pertanian dan perkebunan kawasan. Sejak dibangunnya stasiun Tangerang, kota lama kemudian mulai berkembang menjadi pusat perdagangan dan pada abad ke 19, infrastruktur kawasan mulai terpenuhi dengan baik, salah satunya adalah terbentuknya Jalan Ki Samaun dan Ki Asnawi yang kemudian menjadi akses keluar masuk utama kawasan kota lama dan menjadi pusat kota lama

Pada sekitar abad ke-18 beberapa bangunan rumah tingggal di jalan cilame, masih memiliki bentuk arsitektur pecinan, bangunan di sekitar ini diperkirakan dibangun pada rentan waku yang sama. Perubahan aktivitas kawasan yang cukup signifikan terjadi pada abad ke-19, dimana hampir seluruh lahan kosong yang ada di sekitar koridor ki samaun telah teralokasi untuk permukiman dan ruko. Kawasan ini pun kemudian dikenal sebagai pasar lama oleh masyarakat Kota Tangerang. Bangunan - bangunan tradisional pecinan yang masih menguasai jalan Ki Samaun pun mulai berubah bentuk menjadi ruko - ruko modern, sehingga citra koridor pecinan tidak lagi tampak di Koridor Ki Samaun. Bangunan - bangunan yang masih bertahan hingga saat ini adalah klenteng boen tek bio, museum benteng heritage, stasiun KA Tangerang, dan Mesjid Kalipasir serta Pendopo Kabupaten Tangerang.

Kondisi tersebut kemudian membuat pemerintah mencetuskan rencana revitalisasi kawasan, dengan harapan untuk meningkatkan kembali citra kawasan memlaui restorasi fasad bangunan. Selain itu karena Kota Lama Tangerang memiliki potensi yang cukup besar untuk dikembangkan sebagai aset wisata budaya bagi Kota Tangerang, wilayahnya yang merupakan kawasan multikultural yang menyimpan sejarah perkembangan Kota Tangerang, juga pusat perbelanjaan yang dilengkapi dengan bangunan - bangunan warisan cagar budaya menjadikannya unik. Hanya saja rencana tersebut belum terlaksana hingga saat ini. Tidak ada koordinasi antar dinas yang terkait dengan rencana revitalisasi, produk RDTR dan RTBL yang belum juga disahkan, dan belum adanya upaya untuk pembinaan partisipasi masyarakat menjadi alasam belum efektifnya rencana revitalisasi tersebut, meskipun upaya pembangunan fisik kawasan telah dilakukan sedikit demi sedikit.

\section{Analisis Persepsi Masyarakat Terhadap Fasad Bangunan}

\section{Persepsi Terhadap Warna}

Sebanyak 34\% responden menyatakan tidak setuju dan 26\% responden menyatakan sangat tidak setuju bahwa warna bangunan di sepanjang koridor Ki Samaun terasa seragam atau memiliki warna yang sama. Sebagian besar masyarakat (61\% responden) menyatakan bahwa warna bangunan tidak terlalu memberikan rasa senang namun juga tidak memberikan rasa tidak nyaman untuk berada di dalam kawasan.Sebagian besar responden (57\% responden) menyatakan bahwa warna bukan menjadi faktor utama mengapa pengunjung memasuki bangunan yang dimilikinya, tetapi barang kebutuhan yang ditawarkan. Sebanyak 30\% responden juga menyatakan tidak setuju bahwa warna bangunan di koridor Ki Samaun menimbulkan rasa ketertarikan pengunjung untuk masuk atau mendekati bangunan. 
Sebagain besar responden (43\%) menyatakan bahwa warna bangunan di sepanjang koridor ki samaun tidak ada yang terlalu mencolok. Namun sebanyak 33\% responden menyatakan bahwa terdapat bangunan yang memiliki warna mencolok di Koridor Ki Samaun yaitu Klenteng Boen Tek Bio dan Rumah Duka Boen Tek Bio yang terletak di Jalan Cilame dan Koridor Ki Samaun. Masyarakat menganggap bahwa kedua bangunan tersebut dapat langsung diingat atau dikenali dengan mudah karena warnanya yang mencolok dan mencirikan budaya cina dengan warna merahnya.

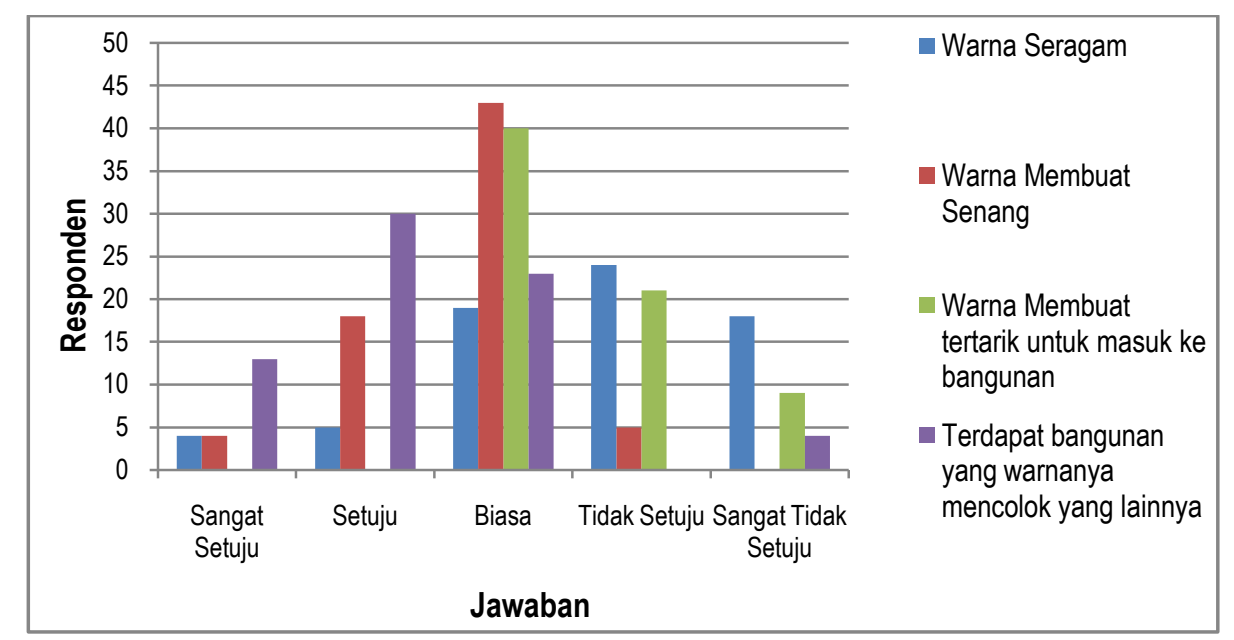

(HasilAnalisis, 2015)

Gambar 2. Persepsi Terhadap Warna Bangunan di Koridor Ki Samaun

\section{Persepsi Terhadap Lebar dan Tinggi Bangunan}

Persepsi terhadap lebar dan tinggi bangunan meliputi bentuk pintu dan jendela, kesamaan lebar dan tinggi bangunan, serta bentuk atap bangunan.

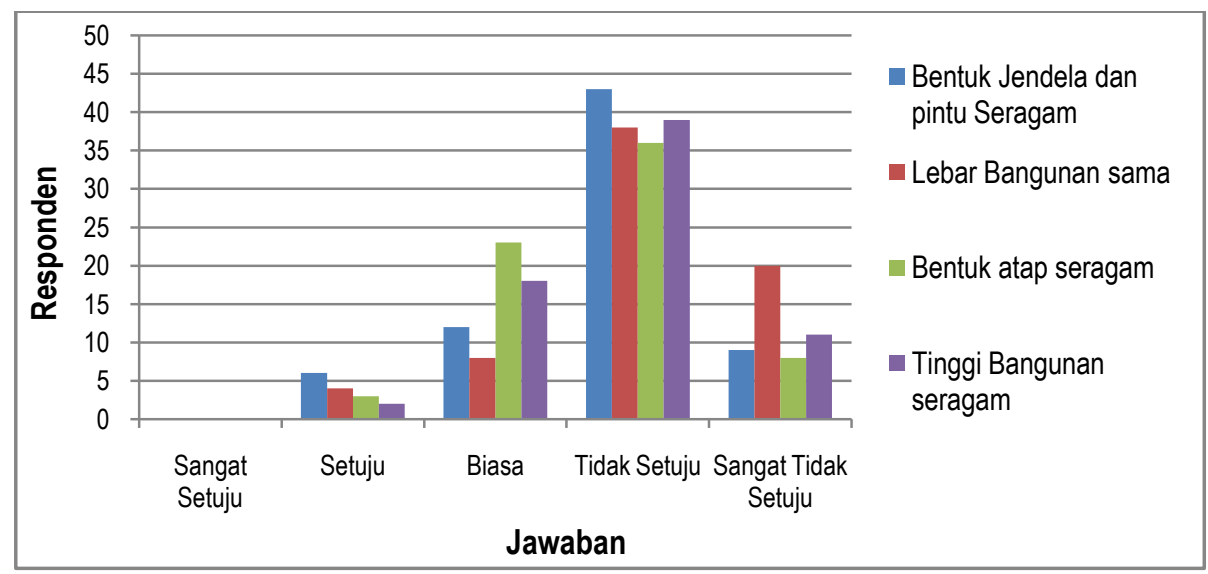

(HasilAnalisis, 2015)

Gambar 3. Persepsi Terhadap Tinggi dan Lebar Bangunan di Koridor Ki Samaun 
Sebanyak $61 \%$ responden menyatakan tidak setuju bahwa bentuk jendela dan pintu pada bangunan di Koridor Ki Samaun seragam, responden menilai bahwa jelas terlihat di hampir setiap gedung bentuk jendela dan ukurannya berbeda - beda. Sebanyak 54\% responden menyatakan tidak setuju dan 29\% responden menatakan sangat tidak setuju bahwa lebar bangunan di koridor ki samaun memiliki lebar yang sama.Sebanyak 51\% responden menyatakan tidak setuju bahwa bentuk atap bangunan di koridor jalan ki samaun memiliki bentuk yang sama, sedangkan $31 \%$ responden menyatakan bahwa bentuk atap tidak sama sekali berbeda, namun juga tidak seragam. Sebanyak 39\% responden menyatakan tidak setuju bahwa tinggi bangunan di koridor jalan ki samaun seragam, sedangkan $26 \%$ di antaranya menyakan terdapat beberapa bangunan yang seragam tingginya, namun jika dilihat secara keseluruhan deret tinggi bangunan tentu tidak seragam dan tidak menimbulkan dampak tertentu.

\section{Persepsi Terhadap Gaya ArsitekturBangunan}

Berdasarkan analisis yang dilakukan, sebanyak 37\% dari total responden menyatakan setuju bahwa gaya arsitektur bangunan merupakan aspek terpenting dalam upaya revitalisasi kawasan. Sebagian besar masyarakat menganggap bahwa gaya arsitektur bangunan merupakan aspek yang perlu ditekankan dalam upaya revitalisasi. Pandangan tersbeut kemudian ditindaklanjuti dengan mencari tahu gaya arsitektur bangunan seperti apa yang dikehendaki oleh masyarakat di koridor Ki Samaun. Sebanyak 34\% responden menyatakan bahwa gaya arsitektur bangunan di koridor jalan ki samaun tidak lagi mencerminkan budaya pecinan. Responden menyatakan bahwa saat ini banyak sekali bangunan dengan gaya arsitektur modern yang ada di koridor Ki Samaun.

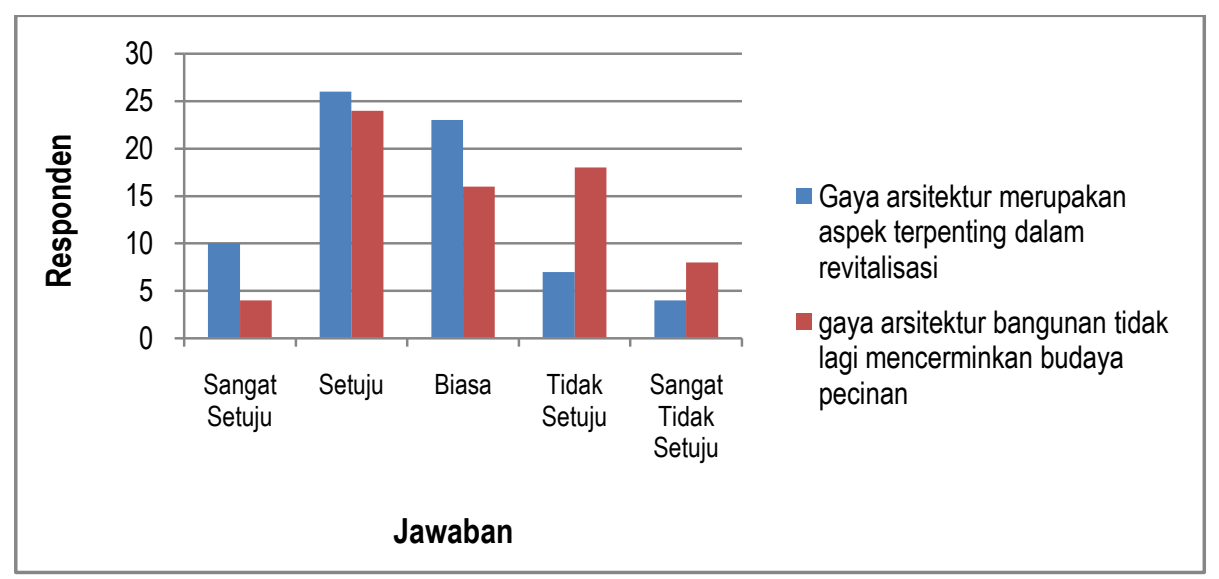

(HasilAnalisis, 2015)

\section{Gambar 4. Persepsi Terhadap Gaya Arsitektur Bangunan di Koridor Ki Samaun}

\section{Persepsi Terhadap Gaya ArsitekturBangunan}

Sebanyak 50\% responden menyatakan bahwa signage atau penandaan yang digunakan pemilik bangunan di sepanjang koridor ki samaun terlihat tidak tertata dengan rapih dan merusak estetika koridor. Masyarakat menilai bahwa spanduk yang digunakan terkadang terlalu besar, namun juga tidak membuat spanduk tersebut terlihat menarik atau mudah dikenali karena letak spanduk-spanduk lainnya yang juga besar dan tidak teratur 
sehingga justru membuat koridor ki samaun terlihat tidak rapih. Sedangkan 34\% responden menyatakan bahwa spanduk - spanduk pada bangunan di koridor ki samaun memang besar, tidak teratur tetapi tidak juga menimbulkan perasaan tidak menyenangkan terhadap koridor ki samaun.

Sebanyak 49\% responden menyatakan biasa saja, bahwa bentuk ornament yang ada pada bangunan di koridor jalan ki samaun terasa sama. Masyarakat menyatakan bahwa banyak gedung - gedung yang tidak memiliki ornament tertentu sehingga tidak terlalu menimbulkan efek tertentu. Sedangkan 36\% responden menyatakan tidak setuju bahwa ornament yang dimiliki bangunan di koriodor jalan ki samaun seragam. Sebanyak $52 \%$ responden menyatakan setuju bahwa terdapat bangunan yang memiliki ornamen mencolok, responden menyatakan bahwa bangunan tersebut adalah bangunan klenteng boen tek bio dan museum benteng heritage yang menggunakan ornamen - ornamen tertentu seperti lampion, patung naga, dan lain sebagainya.

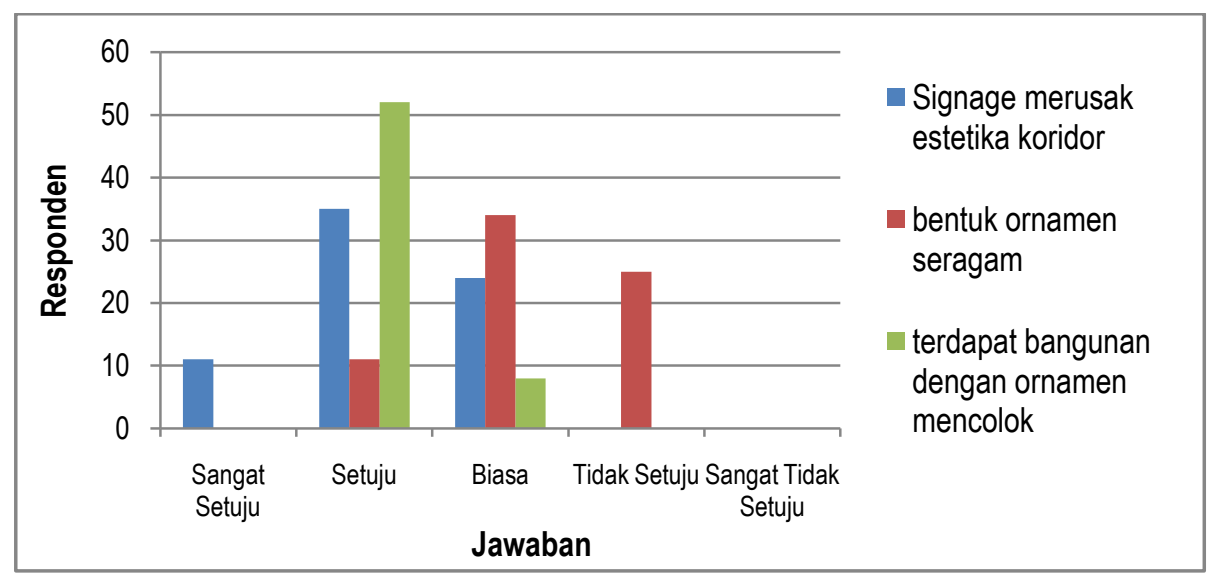

(HasilAnalisis, 2015)

Gambar 5. Persepsi Terhadap Ornamen Bangunan di Koridor Ki Samaun

\section{Analisis Preferensi Masyarakat Terhadap Fasad Bangunan}

\section{Preferensi Terhadap Gaya Arsitektur Bangunan}

Pada dasarnya masyarakat yang bermukim di dan beraktivitas di Jalan Ki Samaun berpendapat bahwa bangunan - bangunan di koridor ki samaun tidak lagi mencerminkan budaya pecinan yang dulunya melekat pada kawasan.

Berdasarkan diagram berikut, maka dapat diketahui bahwa 39\% responden memilih gaya arsitektur pecinan untuk di terapkan di kawasan kota lama (koridor jalan ki samaun, $39 \%$ responden memilih gaya arsitektur modern, 16\% memilih kombinasi antara moderntradisional dan $27 \%$ responden memilih untuk tidak dilakukan perubahan. Masyarakat yang memilih untuk tidak dilakukan perubahan berpendapat bahwa perubahan terhadap bangunan akan memakan waktu yang cukup lama dan tidak perlu merubah bangunan secara total, tetapi dapat dilakukan perbaikan di beberapa bagian saja. 


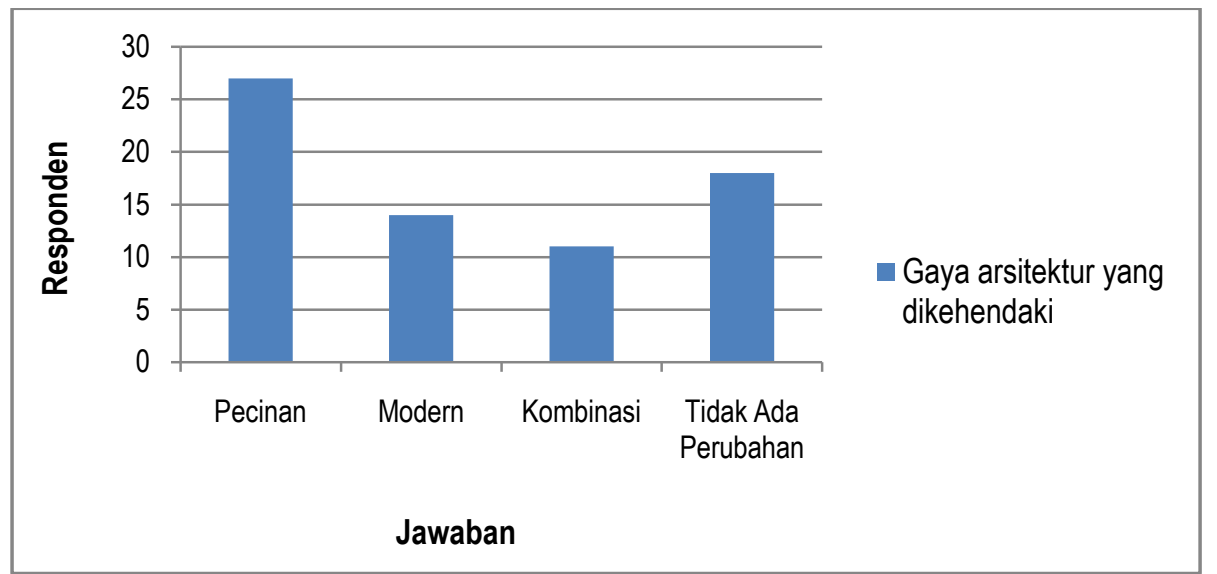

(HasilAnalisis, 2015)

\section{Gambar 6. Preferensi Terhadap Gaya Arsitektur Bangunan di Koridor Ki Samaun}

\section{Preferensi Terhadap Warna Bangunan}

Warna merupakan salah satu aspek terpenting dalam menjaga kualitas estetika bangunan dan kawasan. Berikut ini merupakan preferensi masyarakat dalam penggunaan warna bangunan.

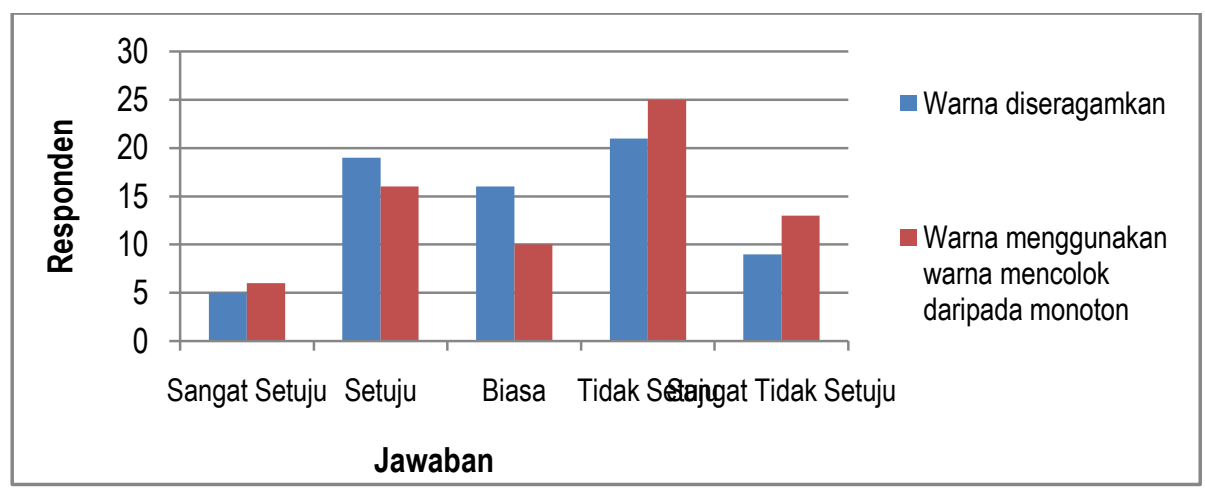

(HasilAnalisis, 2015)

\section{Gambar 7. Preferensi Terhadap Warna Bangunan di Koridor Ki Samaun}

Sebanyak 34\% responden menyatakan setuju dan 9\% responden menyatakan sangat setuju bahwa lebih baik warna bangunan di koridor jalan ki samaun disama ratakan. Responden yang meyatakan setuju beranggapan bahwa jika warna bangunan di koridor jalan ki samaun di sama ratakan, dapat lebih memberikan kesan bahwa koridor ki samaun merupakan kawasan kota lama Tangerang, dan dapat lebih mudah untuk dikenali. Sebanyak 36\% responden menyatakan tidak setuju bahwa lebih baik bangunan di koridor jalan ki samaun menggunakan warna - warna yang mencolok dibandingkan warna - warna yang monoton atau lembut. Sedangkan sebanyak $23 \%$ 
responden menyatakan setuju bahwa lebih baik bangunan menggunakan warna yang mencolok agar dapat menarik perhatian pengunjung, dan lebih mudah untuk dikenali.

\section{Preferensi Terhadap TinggidanLebar Bangunan}

Pada dasarnya masyarakat dapat merasakan dan mengenali dengan jelas bahwa tinggi bangunan di koridor jalan ki samaun berbeda - beda, sebagian dari responden juga menyatakan bahwa tinggi bangunan yang seragam hanya dapat ditemui pada pertigaan jalan ki samaun-ki asnawi. Berikut ini merupakan preferensi masyarakat terhadap tinggi bangunan di koridor ki samaun:

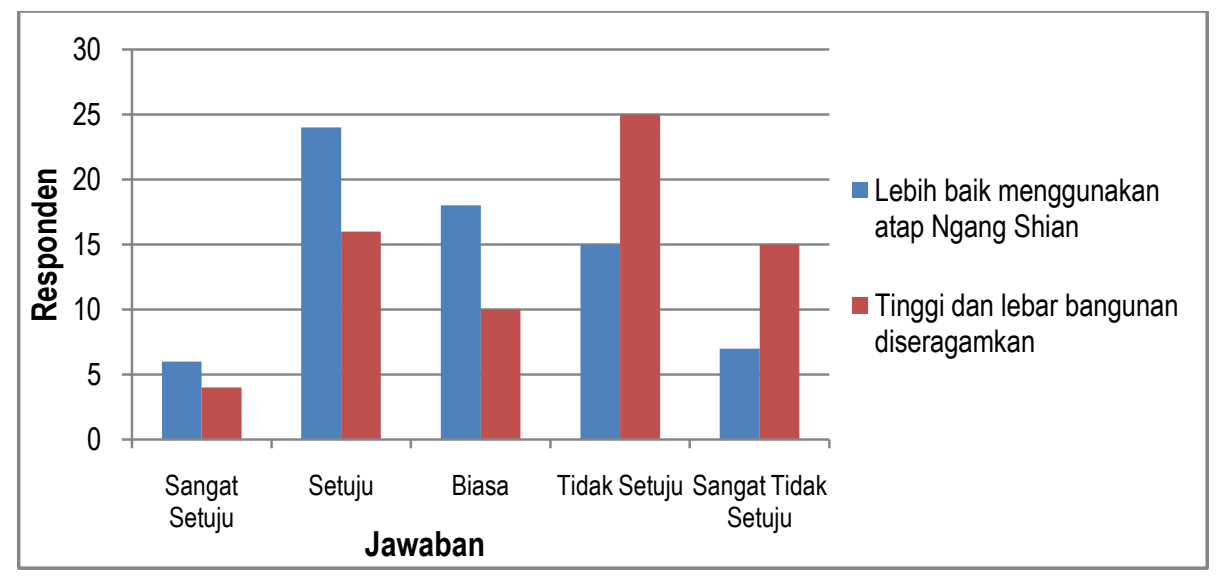

(HasilAnalisis, 2015)

\section{Gambar 8. Preferensi Terhadap Tinggi dan Lebar Bangunan di Koridor Ki Samaun}

Sebanyak 36\% responden menyatakan tidak setuju, jika tinggi bangunan di koridor jalan ki samaun seluruhnya di sama ratakan. Sedangkan 23\% di antaranya setuju, tinggi bangunan di sama ratakan. Responden yang memilih tidak setuju berpendapat bahwa mengenai tinggi bangunan lebih baik dipertahankan apa adanya seperti sekarang, karena modifikasi bangunan pada dasarnya juga terletak pada pemilik bangunan. Sebanyak 34\% responden menyatakan setuju, bahwa lebih baik bangunan - bangunan yang masih memiliki gaya arsitektur pecinan tetap mempertahankan bentuknya, biarpun hanya atap yang masih bergaya atap Ngang Shian. Sedangkan $21 \%$ diantaranya menyatakan tidak setuju jika atap bangunan dibiarkan saja memiliki bentuk pelana.

\section{Preferensi Terhadap OrnamenBangunan}

Ornamen bangunan merupakan salah satu aspek dari fasad bangunan yang memberikan kemudahan dalam mengidentifikasi budaya yang tercermin dalam bangunan tersebut. Berikut ini merupakan preferensi masyarakat terhadap ornamen bangunan atau penandaan. 
Sebanyak 47\% responden lebih memilih menggunakan papan informasi dibandingkan spanduk, karena akan lebih memberikan kesan teratur dibandingkan spanduk. Sedangkan sebanyak 19\% responden lebih memilih menggunakan spanduk daripada papan informasi, hal ini dikarenakan spanduk memiliki harga lebih murah, dan dapat dipasang dengan mudah pada bangunan dan dengan berbagai ukuran. Sebanyak $46 \%$ responden menyatakan setuju bahwa lebih baik terdapat ruang khusus untuk meletakkan papan informasi atau spanduk agar dapat lebih mudah untuk dikenali. Sedangkan $20 \%$ responden menyatakan tidak setuju jika spanduk atau papan informasi dipindahkan atau tidak menempel pada fasad bangunan.

Sebanyak 30\% responden menyatakan setuju bahwa ukuran spanduk lebih baik tidak terlalu besar sehingga tidak menutupi fasad bangunan, namun 26\% di antaranya menyatakan tidak setuju jika ukuran spanduk tidak terlalu besar, karena menurut responden, jika ukuran spanduk tidak besar maka pengunjung akan merasa kesulitan untuk mengenali bangunan dan barang kebutuhan apa yang dijual oleh pemilik bangunan tersebut.Sebanyak $47 \%$ responden menyatakan setuju jika terdapat ornamen khusus yang mencirikan budaya kawasan diletakkan pada bangunan, agar dapat menimbulkan minat tambahan bagi pengunjung untuk memasuki kawasan dan bangunan di koridor ki samaun. Sedangkan 21\% diantaranya menyatakan tidak setuju karena tidak semua bangunan yang ada di koridor ki samaun memiliki fungsi yang sama dan menjual barang kebutuhan yang mencirikan pecinan.

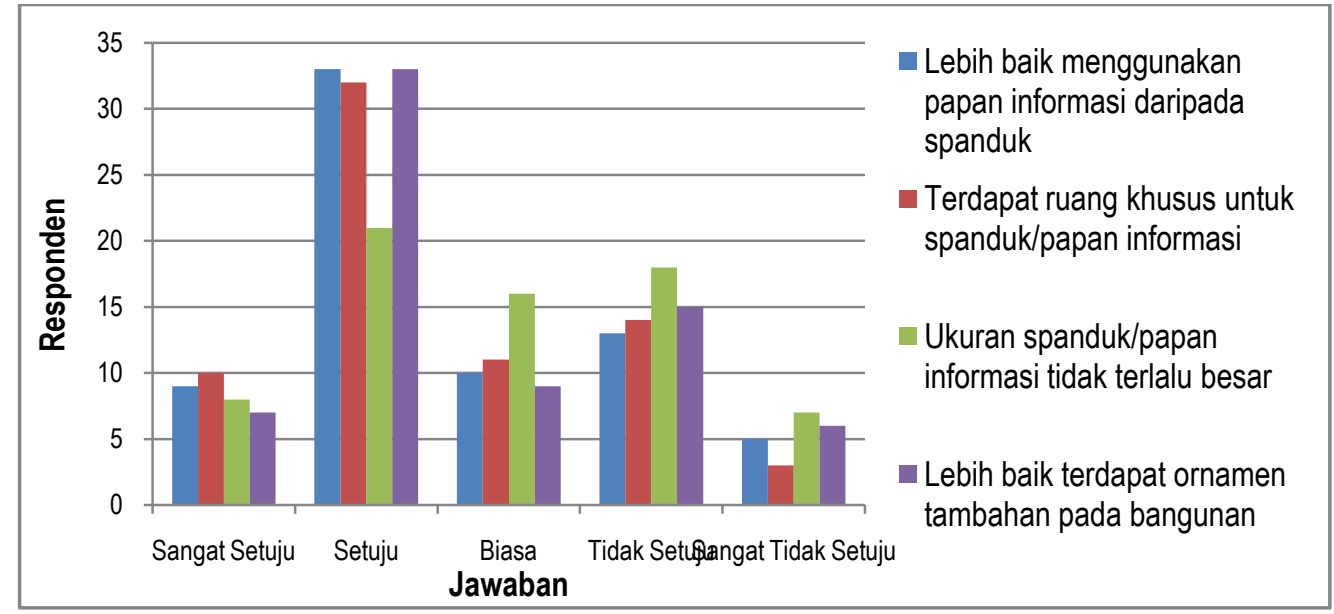

(HasilAnalisis, 2015)

\section{Gambar 9. Preferensi Terhadap Ornamen Bangunan di Koridor Ki Samaun}

\section{Kesimpulan}

Penelitian ini dapat menjawab bahwa pada dasarnya preferensi masyarakat terhadap fasad bangunan di koridor jalan ki samaun memiliki beberapa keselarasan dengan program yang disebutkan dalam rencana revitalisasi kota lama sebagai berikut, Atap merupakan salah satu elemen fasad bangunan yang dapat dengan mudah dikenali, 
terutama jika bangunan itu dibangun dengan pengaruh budaya yang melekat di lingkungan sekitarnya. dan pada elemen atap ini masyarakat dapat dengan mudah mengenali bahwa tidak terdapat keseragaman bentuk atap pada bangunan di Koridor Jalan Ki Samaun dan sebagian besar juga tidak lagi menggunakan atap model Ngan Shiang yang merupakan ciri atap bangunan pecinan. Warna bangunan juga menjadi salah satu aspek yang dapat dibedakan dengan baik oleh masyarakat. Masyarakat menyatakan bahwa warna bangunan di Koridor Jalan Ki Samaun tidak memiliki keseragaman dan terdapat bangunan yang memiliki warna lebih mencolok dari bangunan lainnya, yaitu klenteng Boen Tek Bio dan Rumah Duka Boen Tek Bio dengan warna merah terangnya. Lebar dan Tinggi bangunan merupakan salah satu aspek yang dapat digunakan untuk mengetahui persepsi masyarakat terhadap kondisi visual kawasan (Bentley et al, 1985), apakah masyarakat memberikan perhatian terhadap proporsi bangunan secara detail, atau hanya memperhatikan bentuk bangunan keseluruhan, atau hanya memperhatikan keseragaman bentuk jendela dan pintunya saja. Aspek lebar dan tinggi bangunan yang digunakan dalam penelitian ini mencakup jendela, lebar bangunan, tinggi bangunan dan bentuk atap bangunan. Berdasarkan analisis yang telah dilakukan di atas, sebagian besar responden menyatakan bahwa bentuk jendela, lebar bangunan, tinggi bangunan dan bentuk atap bangunan di sepanjang koridor Ki Samaun tidak sama.

Pada dasarnya masyarakat memiliki keinginan untuk menghidupkan kembali budaya pecinan yang merupakan cikal bakal kawasan kota lama. Adapun masyarakat memandang bahwa dalam pelaksanaan revitalisasi kawasan, hal yang perlu diperhatikan adalah gaya arsitektur bangunan. Masyarakat dan pemerintah juga memiliki kesamaan visi dalam hal restorasi fasad bangunan, kedua pihak setuju bahwa lebih baik bangunan dikembalikan gaya arsitekturnya ke gaya arsitekur bangunan yang semula, yaitu gaya arsitektur pecinan. Preferensi masyarakat terhadap warna bangunan adalah lebih baik warna bangunan diseragamkan, menggunakan warna monoton.

Pada aspek dekorasi bangunan, masyarakat lebih memilih menggunakan papan informasi dengan desain yang menarik dan tidak menutupi bangunan seperti spanduk yang mereka gunakan saat ini. Aspek ini juga cukup selaras dengan rencana pemerintah yang menetapkan desain media signage yang terpisah dari fasad bangunan dan memiliki desain yang menarik. Pada dasarnya Aspek Keseragaman dalam perancangan fasad kawasan merupakan aspek yang terpenting dalam pelaksanaan revitalisasi Kota Lama. Adanya keseragaman pada gaya arsitektur bangunan, warna bangunan, desain dekorasi bangunan seperti signage menjadi preferensi masyarakat dalam upaya revitalisasi bangunan di KoridorJalan Ki Samaun. Masyarakat menilai bahwa salah satu hal yang dapat memberikan kemudahan dalam mengenali identitas suatu kawasan adalah keseragaman atau kemiripan bentuk antar bangunan yang ada di dalamnya.

\section{Rekomendasi}

Rekomendasi dari hasil penelitian ini dapat diberikan kepada 3 pihak yaitu pemerintah, masyarakat dan peneliti lanjutan. Bagi pemerintah sebaiknya memperbaiki koordinasi antar dinas dan dengan masyarakat, menyampaikan informasi terkait revitalisasi dan restorasi kawasan kepada masyarakat secara cermat dan seksama, selain itu diperlukan aturan terkait modifikasi bangunan di Koridor Jalan Ki Samaun, terutama bagi bangunan 
yang masih memiliki bentuk dan gaya arsitektur aslinya. Hal ini dilakukan untuk menekan laju perubahan bangunan di Koridor Jalan Ki Samaun.

Bagi masyarakat sebaiknya Memanfaatkan kawasan kota lama yang peduli dengan keberlanjutan budaya, emnggunakan ruang terbuka secara humanis, dan peduli terhadap lingkungan dengan menjaga kebersihan dan keindahan kawasan. Bagi penelitian lanjutan, penelitian ini dapat dikembangkan lagi seperti penelitian mendalam tentang kajian finansial pengembalian fasad bangunan dan upaya penerapan insentif dan disinsentif. Pengembalian fasad bangunan lama tidak akan terlaksana tanpa dukungan yang kuat dari pihak pemerintah, pengusaha dan pemilik rumah. Untuk itu upaya kajan pendanaan dapat menjawab secara biijak upaya pelestarian bangunan yang ada di kawasan kota lama.

\section{DaftarPustaka}

Askari, Amir H. dan Kamariah Binti Dola. 2013. "Influence of building Façade Visual Element on Its Historical Image: Case of Kuala Lumpur City, Malaysia.” Jurnal Design and Build Environment, Vol. 5, pp. 49-59.

Brown, G. dan Gifford, R. 2001. "Architects Predict Lay Evaluations of Large Contemporary Buildings: Whose Conceptual Properties?” Jurnal Environmental Psychology, Vol. 21. pp. 93-99

Coeterier, J. F. 2002. “ Lay People’s Evaluation of Historic Sites.” Jurnal Landscape and Urban Planning, Vol. 59. pp. 111-123.

Cresswell, John W. dan Vicky L. Plano Clark. 2007. Designing and Conducting Mixed Methods Research. Thousand Oaks, CA: SAGE Publications.

Cubukcu, E., dan Kahraman, I. 2008. "Hue, Saturation, Lightness, and Building Exterior Preference: An Empirical Study in Turkey Comparing Architects' and Nonarchitects' Evaluative and Cognitive Judgments. "Jurnal Color Research and Application, Vol. 33. pp. $395-405$.

Hibrawan, Abdullah P.W. 2008. "Kajian Karakter Fasade Bangunan - Bangunan Rumah Tinggal Kolonial di Kawasan Perumahan Tjitaroem Plein Bandung." Tesis Tidak Diterbitkan. Program Studi Perencanaan Wilayah dan Kota, Sekolah Arsitektur, Perencanaan dan Pengembangan Kebijakan. Institut Teknologi Bandung, Bandung.

Tashakkori, A., dan Teddlie, C. 2003. Handbook of Mixed Methods In Social And Behavioral Research. California: Sage Publication, Inc.

Utaberta, N. et al. 2012. "Building Façade Study in Lahijan City, Iran: The Impact of Façade's Visual Elements on Histroical Image” Jurnal World Academy of Science, Engineering and Technology, Vol. 6, pp. 582-587. 